\title{
FAKTORE VERANTWOORDELIK VIR DIE INSINKING EN OPLEWING IN DIE GEESTELIKE LEWE VAN OU-ISRAEL*
}

W Vosloo

Die insinking en oplewing in die geestelike lewe van ou Israel spruit voort uit 'n wye verskeidenheid faktore en kan op verskillende maniere benader word. In hierdie lesing wil ek my bepaal by die belangrikste faktore en hulle vanuit enkele gesigshoeke belig.

Omdat ' $n$ volk se geestelike lewe bepaal word deur dié van sy enkelinge sal ons eers die klem laat val op die stryd teen die sonde by die indiwidu. Daarna werp ons ' $n$ blik op die faktore en strominge wat geestelike insinking en geestelike oplewing by die volk veroorsaak het. Geestelike insinking is primêr 'n menslike verantwoordelikheid. Daarom sat ons dit vanuit drie tipes menslike gesigshoeke bekyk, te wete die psigologiese, sosiologiese en politieke hoeke. Alhoewel die mens ook betrek word by en instrument is in die bewerking van geestelike lewe, is dit nogtans primêr God wat geestelike oplewing tot stand bring. Daarom sal ons kyk na drie maniere waarop God die volk tot herlewing geroep het, naamlik deur die woord, die daad en die Gees.

\section{Die stryd by die indiwidu}

In Genesis 4:7 vind ons ' $n$ sleutel tot die verstaan van die stryd teen die sonde by die mens. Dit lui: "... die sonde wag jou in daarbuite en hy wil jou in sy mag kry. Maar jy moet oor hom heers." Met hierdie woorde van die Here aan Kain word gesê: Die gevaar van die sonde is 'n aktiewe mag, maar die mens beskik oor die moontlikheid om dit te oorwin. Daarmee is die stryd in die gees van die mens onder woorde gebring. Insinking by die enkeling is wanneer die sonde die mens beheer; oplewing vind plaas wanneer die mens oor die sonde heers.

Deur die res van die Bybel heen word hierdie eindelose stryd in gebeurtenis na gebeurtenis bekendgestel. Dis jaloesie by Kain, gierigheid by Jakob, magsug by Abimelek, seun van Gideon, onbeteuelde seksdrang by Dawid. Al hierdie insinkings in die lewens van bepaalde persone word nie maar net as menslike swakhede geskets nie. Jaloesie en gierigheid en magsug en seksuele vergrype en talle ander sondes word voorgestel as magte wat die mens wil beheers. Dis magte van aftakeling wat nie passief bejeën mag word nie. Sonde is ' $n$ aktiewe mag wat net deur ' $n$ besliste, doelgerigte en dinamiese teenoptrede gestuit kan word. Anders gestel, geestelike insinking volg op die onderskatting van die magte wat die gees van die mens wil beheer; geestelike oplewing volg op kragdadige optrede téén hierdie magte.

"Lesing gelewer tydens die jaarlikse predikantekonferensie met die opening van die Teologiese Fakulteit van die Ned. Geref. Kerk aan die Universiteit van Pretoria op 7 Februarie 1984. 
Dis opvallend dat daar in Genesis 4 nie gesê word hóé die mens oor die mag van die sonde kan heers nie. Dis asof die klem eerder gelê word op die verantwoordelikheid van die mens self in hierdie stryd om sy gees. Daardeur word hy opgeroep om aktief teen die geestelike verval op te tree. "

Dis eers elders in die Ou Testament waar meer gesê word oor die hoe van die heers oor die sonde. Veral die Psalms en Wysheidsliteratuur gee besondere aandag aan die stryd om die gees van die mens. Daarvoor word na die "hart" van die mens verwys. Vir ons dui "hart" gewoonlik op emosie, maar in die Ou Testament is dit anders. Daar word die niere beskou as die setel van emosie (Spr 23:16), terwyl die hart die setel is van die denke en besluitnemings. Dit is dus die setel van die menslike gees. ${ }^{2)}$ Die Psalms en Wysheidsboeke sien die geestelike verval van die mens as iets wat (volgens die letterlike vertaling van die Hebreeus) in sy "hart", sy gees of gemoed ontstaan. (Vgl. byvoorbeeld Ps 10:6, 11, 13; 14:1; 53:2; Spr 6:18; 11:20; 12:20). Daarom is daar 'n stryd om die "hart" van die mens. In sy "hart" moet die mens God se gebooie bewaar (Spr 3:1; 7:3). Sy "hart" moet hom op die regte pad hou (Spr 7:25; 23:19) en moet wysheid en onderwysing nastreef (Spr $17: 3 ; 24: 12$ ). Daardeur word die belangrike rol van die wilsbeslissing van die mens in sy geestelike lewe duidelik gestel. Dáár begin die geestelike insinking van die indiwidu en daarom ook van 'n hele gemeenskap.

Die "heers" oor die sonde is volgens die Psalms en Wysheidsboeke ook geleë in die "hart" as die sentrum van die wilsbeslissings van die mens. Dis op die vlak van die wil dat ' $n$ besluit vir of teen sonde geneem word. Dáár moet daar standpunt ingeneem word wat tot geestelike verval of herlewing kan lei.

Tog blyk dit gaandeweg dat dit nie ' $n$ aksie van die mens alleen is nie. In die Spreukeboek word gesê dat dit eintlik die "diens aan die Here" en die "kennis van God" is wat die mens instaat stel om die regte wilsbeslissings te maak (Spr $1: 7 ; 23: 1 ; 9-10$ ). Daarmee word bedoel 'n noue verhouding met en persoonlike belewing van God. Kortom, die verhouding waarin ons tot God staan en ons ervaring met Hom bepaal hoe ons wilsbesluite is. Dit weer is bepalend vir ons oorwinnings en neerlae op die gebied van die gees.

Gedaǵtig aan die mens se onvermoë om hierdie pad self te loop, gaan God egter 'n stap verder. Hy beloof om self aan die mens 'n nuwe "hart" te gee (Esg 36:26 - 27). As die mens self dan nie tot die regte beslissings kan kom nie, sal God aan hom 'n nuwe denkpatroon, 'n nuwe wilsvertrekpunt gee. Daaruit vloei 'n nuwe verhouding met God voort; dít laat hom "heers" oor die sonde. Hoewel geestelike oplewing by die indiwidu dus gekenmerk word deur die regte persoonlike wilsbeslissings, kan dit nooit los gesien word van die vernuwende werking van God en sy Gees nie. Dié saak word egter later bespreek.

\section{Geestelike insinking by die volk}

\section{1 'n Psigologiese gesigshoek}

Uiteraard sou 'n mens 'n hele verskeidenheid geestesstrominge kon aandui 
wat in die loop van die geskiedenis van ou-lsrael tot geestelike insinking gelei het. Wanneer ons ons toespits op die tyd wat die val van elk van die twee ryke voorafgegaan het, kan daar egter ' $n$ kenmerkende stroming wat by elkeen onderskeidelik werksaam was, herken word. In die Noordryk was dit materiële selfgenoegsaamheid en in die Suidryk was dit godsdienstige selfversekerdheid.

\subsubsection{Materiële selfgenoegsaamheid}

Die bewindjare van Jerobeam II in die Noordryk was 'n periode van besondere welvaart. ${ }^{3)} \mathrm{Hy}$ het baie van die omliggende streke aan Israel onderwerp (2 Kon 14:25-28) en deur buit en belastings die staatskas gevul. Die profeet Amos beskryf die voorspoed en rykdom in terme van huise van gekapte klippe en pragtige wingerde (5:11), huise (3:15) en bedde met ivoorinlegsels (6:4) en rojale leefwyse $(6: 4-6)$. Hierdie welvaart het gelei tot ' $n$ gevoel van sorgvryheid en selftevredenheid met geen gedagte aan enige onheil nie sodat Amos moes sê: "Ellende wag vir dié wat so rustig in Sion woon, dié wat so veilig voel op Samariaberg ..." $(6: 1)$ en "Ellende wag vir dié wat smag na die dag van die Here ..." (5:18). "Ellende ...", want in die spoor van die welvaart en selfgenoegsaamheid het 'n hele reeks oortredings gevolg: uitbuiting van minderbevoorregtes $(2: 6-7 ; 4: 1,5: 11 ; 8: 4-6)$, immorele lewe $(2: 7)$, verdraaiing van die regspraak $(5: 7,10)$, korrupsie $(5: 12)$ en bedrog $(8: 5)$. Dis nie dat hulle die Here verwerp het nie, maar dat hulle Hom op hulle voorwaardes gedien het. So het hulle 'n godsdiens ontwerp wat hulle begeertes gepas het $(5: 21-24)$. 4) Die voorspoed het Israel tot ' $n$ valse godsdiens verlei. Die seën van sukses het geword die vloek van verval. En te midde van die materiële voorspoed het Israel in geestelike armoede geleef sodat die Here moes sê: "Ek verafsku die hooghartigheid van Jakob, Ek het 'n weersin in sy mooi huise!" $(6: 8)$. Skaars veertig jaar later het die onkeerbare oordeel gevolg. Samaria is verwoes en die Noordryk het finaal tot 'n einde gekom. (Vgl. Esg 16:49-50).

\subsubsection{Godsdienstige selfversekerheid}

In die Suidryk was die situasie net andersom. Die geestelike insinking wat die val van die ryk voorafgegaan het, het nie met materiële voorspoed verband gehou nie, maar met die volk se godsdienstige selfversekerdheid. Die boek Jeremia vertel 'ons meer hiervan. Anders as die Noordryk, was Juda bewus van die dreigende onheil. Hulle het ook besef dat Juda alleen nie die onheil sou kon afweer nie. Daarom het hulle al hulle hoop op die tempel in Jerusalem gesit. Hulle het gemeen God was onvoorwaardelik gekompromitteer om hulle te beskerm. Solank hulle maar 'n tradisionele godsdiens beoefen, die sabbat hou en die feeste vier, die tempel besoek en offers bring, mót die Here hulle bewaar. Hulle was tevrede dat die Here in hulle midde was en vir hulle sou sorg. Immers, was hulle dan nie sy volk nie? Het Hy nie beloltes aan Dawid gemaak nie? "Dit is die Here se tempel, dit is die Here se tempel, dit is die Here 
se tempel!" was hulle kreet (Jr 7:4).

So het godsdienstige selfversekerdheid geen ruimte gelaat vir godsdienstige selfkritiek nie; en sonder selfkritiek het Juda blind geword vir sy verantwoordelikhede as volk van God. Hulle het die basiese vereistes vir 'n volk van God oortree: minderbevoorregtes onderdruk, die Wet verontagsaam en ander dinge soos gode vereer (7:5-9). Al het jy die mooiste gebou wat aan God gewy is, al hou jy gereeld die mooiste dienste, al kom jy na sy huis en bring jy getrou jou gawes - God vra meer as dit. Hy vra 'n lewe wat aan Hom gewy is, ' $n$ daaglikse optrede teenoor ander mense wat getuig dat jy die Here as God erken $(7: 5-6 ; 22: 16)$. Daarom roep Hy tot bekering $(25: 5 ; 26: 3)$, want Hy soek nie leë formaliteite nie, maar 'n "hart", 'n insig en denkwêreld wat Hom as God erken (24:7).

\section{2 'n Sosiologiese gesighoek}

Vanaf die vroegste tye was daar ' $n$ kontras tussen die stad en platteland. Die stad is altyd met ' $n$ mate van skeptisisme beskou en die platteland met ' $n$ mate van snobisme. Die Ou Testament is van die vroegste geskrifte wat aan hierdie saak aandag gee.

Vroeër jare toe die Israeliete self nog nie stedelinge was nie, het daar reeds bepaalde opvattings oor die stad ontstaan na aanleiding van wat Israel van stede gesien en ervaar het. Toe Israel later self stede bewoon, het heelwat van hierdie beskouings nog oorgebly. Hieruit spreek reeds duidelik dat Israel nie afwysend was teenoor stede en stadsbewoning as sodanig nie. Eerder het dit om bepaalde misstande in die stad gegaan. So het die stad mettertyd simbool geword van sekere tekortkomings in die samelewing, simptome van insinking in die geestelike lewe van die volk..$^{51}$

In Genesis 4:17 word die totstandkoming van die eerste stad verhaal. Kain bou dit ten einde agter mure beskerming teen sy agtervolgers te vind. Daarmee word die stad getipeer as 'n toevlugsoord vir uitgewekenes. Losgemaak van die bindinge van familie en gemeenskap wat steeds tot verantwoording roep, kan die mens wegraak agter die beskermende mure. Dis mure van klip en steen, maar ook mure van mensemassas wat geen verantwoording eis nie. Losgemaak van sy natuurlike bindings, beskermd agter mure en mense, raak hy los van sy lewensnorme. Dié losheid kan in die beskermende situasie van die stad ontaard in die soort tirannie waarvoor stede destyds bekend was en uiting vind in ' $n$ wraaksug soos verwoord in die wraaklied van Lameg (Gn 4:23-24). Losheid van bloedbande en tradisionele norme en verskuildheid in die massa is die voorspel tot geestelike verval.

Die vertelling oor die toring van Babel in Genesis 11:1-9 is geen kritiek op die stad nie, maar op die misbruik wat mense van die stadsituasie maak. Hier word vertel hoedat die mens in sy grootheidswaan homself teenoor God probeer stel het, maar in verwarring uiteen is. "Babel" verklaar nie soseer die naam van die stad nie, as die karakter daarvan. Daarom dui die klankspel "Babel - babél" op die oortuiging dat 'n stedelike samelewing ' $n$ plek is van 
verwarring en disharmonie. Omdat daar so baie mense bymekaar is, is die geleentheid tot grootheidswaan (hubris) soveel groter. En grootheidswaan is dié sonde wat die Ou Testament in die felste terme veroordeel.

Die verhaal van Lot en die stad Sodom (Gn 13-14, 18-19) wil weer 'n ander gevaar beklemtoon. Al is die stad nog so veilig en voorspoedig, Genesis 14 toon dat dit ook maar kwesbaar is ten spyte van sy mure en grendels. Al is dit mooi en aanloklik, dit huisves morele waardes wat tot vernietiging lei ( $\mathrm{Gn}$ $18-19)$. Ten spyte van al sy goeie voornemings en opregte pogings word Lot en sy gesin ingetrek in die sondige lewenswaardes van die Sodomiete, weggesteek agter mure van voorspoed, kultuur en sukses. Daarmee het die stad simbool geword van geestelike verval en word Sodom en Gomorra telkens in die Ou Testament as voorbeeld van groot sondigheid gebruik (vgl. Jes 1:10; 3:9;1 Jr 23:14; Esg 16:49).

Ook die res van die Ou Testament sien die stad in 'n ambivalente gedaante: Dis teken van die prestasie van die mens waar kuns en kultuur en kundigheid floreer. Tog is dit ook simbool van die lelikste in die mens: verwaandheid, morele verval, verdrukking, tiranie, verdraaide lewenswaardes. Dié soort van stadslewe lei tot die geestelike insinking van ' $n$ volk. Daarom waarsku die OT: Die sekuriteit van beskermende (mense) mure, die prag van spoghuise en -tuine, die skeppingskrag van die kunste, die vindingrykheid van die tegnologie - hoe heilsaam dit ook al mag wees, kan ook demonies word. Die mure kan middel tot eksklusiwiteit en onderdrukking word, huise en tuine kan hebsug en verwaandheid kweek en die prestasies van die beskawing kan selfvernietigend word.

Tog lê die fout nie in die stad self nie. Dit lê in die simbool van "agter mure", "tussen mensemassas". Daarom te meer is dit opvallend dat die toekomsvisie van die Ou Testament nie ' $n$ tuin is nie, maar 'n stad. Maar dis 'n stad sonder mure (Esg 38:11), een waarvan God self die muur is (Sg 2:5). En dit is die antwoord van die Ou Testament op die geestelike insinking van die stadsatmosfeer. As God die muur is, as Hý die een is waaragter die mens skuiling soek, kan die verval nooit intree nie.

\section{3 'n Politieke gesigshoek}

Israel was nie 'n homogene eenheid nie. In die begin slaag Dawid daarin om 'n eenheidsryk rondom sy persoon te stig en uit te bou. Salomo kon nog die vrugte hiervan pluk, maar die dwase optrede van Rehabeam het die ou verskille tussen die Noorde en die Suide weer laat opvlam. Dit het tot 'n skeuring gelei wat die eiesoortigheid van elke deel opnuut beklemtoon het. Gesien teen die agtergrond van uiteenlopende geografiese omstandighede en bepaalde aksentverskille in die oorlewerings van die tradisies uit die verlede, het daar ten spyte van 'n gemeenskaplike taal en 'n gemeenskaplike geloof in die Here tog groot verskille ontstaan. Die politieke situasie het ook groot effek gehad op die geestelike lewe van die onderskeie ryke. 


\subsubsection{Die Noordryk}

In die Noordryk was die koningskap nie onherroeplik aan 'n bepaalde dinastie verbind nie. Van die negentien konings het net twee deur salwing koning geword. Ses het die troon geërf en die ander elf het dit deur staatsgrepe bekom. Dié situasie het onstabiliteit veroorsaak en die profetebeweging aktief laat optree (vgl. die salwing van Jehu in 2 Kon 9).

Die gevaar is deur twee ander sake vererger: ${ }^{6)}$

Eerstens het Kanaänitiese elemente ' $n$ groot deel van die bevolking uitgemaak, sodat aanbidders van die Here vroeg reeds hulleself teenoor hierdie elemente moes afgrens. Die feeste en ou tradisies van die verlossing uit Egipte en die Verbondsluiting het hierin 'n belangrike rol gespeel. Reeds die eerste koning, Jerobeam, het sinkretistiese kultusse by Dan en Betel ingestel ten einde die invloed van Jerusalem teen te werk en ook die lojaliteit van die Kanaänitiese onderdane te wen. Koning Omri het dié beleid verder uitgebou deur gelyke regte vir sowel Israeliete as Kanaäniete na te streef.

Hierdie binnelandse gevaar is tweedens deur ' $n$ buitelandse een versterk. Geografies was die Noordryk minder afgesonderd as Juda (die Suidryk) en nader aan die groot sentra van vreemde kultusse soos Aram en Tirus, met wie handels- en krygsbande gehandhaaf is. Buitelandse beïnvloeding was gevolglik meer aktueel as in die suide. Toe Omri se seun, Agab, boonop met Isebel, 'n prinses uit Tirus trou, is daar oorgegaan tot doelbewuste uitroeiing van die godsdiens van die Here en die uitbouing van die Baäl-godsdiens. Hierdie toleransie en selfs bevordering van Baälisme het vroeg reeds reaksie uitgelok van die kant van die toegewyde Israeliete. Dis met name die Nasireërs, Regabiete, plattelandse leviete en die profeteskole wat sterk weerstand gebied het teen die Kanaäniseringsproses.

In die Noordryk vind ons dus twee strominge: Die amptelike beleid wat veral om politieke redes gaandeweg al meer weggedryf het van die oorspronklike diens van die Here en geestelike insinking veroorsaak het; en die toegewyde groepe wat al sterker in hulle geloofsoortuigings geword het." Omdat die koning en sy regerende party egter die mag in die hand gehad het, het hulle geleidelik die land na 'n geestelike afgrond toe gelei.

\subsubsection{Die Suidryk (Juda)}

Anders as in die Noordryk, was Juda onlosmaaklik verbind aan die Dawidshuis en sy erfregtelike koningskap. Dit het bygedra tot ' $n$ gevoel van sekuriteit en selfversekerdheid wat grotendeels in die Noorde ontbreek het. Daarby was Juda weens sy ligging betreklik beskermd teen invloede van buite met slegs 'n klein minderheid Kanaäniete binne sy grense. Die vrugbaarheidsgodsdienste het dus skynbaar vir Juda geen bedreiging ingehou nie. Daarom is dit nie sterk bekamp nie sodat heidense idees tog geleidelik in die kultus en godsdiens ingesluip het. ${ }^{81}$

As gevolg van politieke redes het Dawid en Salomo ' $n$ beleid van groter 
toegewendheid teenoor die binnelandse Kanaäniete, met name die Jebusiete van Jerusalem, gevolg. Salomo het selfs doelbewus ontslae geraak van sommige voorstanders van die ou tradisionele opvattings en sy hofhouding geskoei op die model van die omwonende volke.9" Die tempel het hy volgens Kanaänitiese model gebou. Dis ook om politieke redes dat hy met heidense prinsesse getrou en hulle godsdienste in Jerusalem toegelaat het.

Ten spyte van die amptelike diens aan die Here het die sinkretisme gaandeweg die godsdiens van Juda binnegedring. Onder Rehabeam, wie se moeder ' $n$ Ammoniet was, het dit verder uitgekring. Daarna verneem ons telkens van allerlei heidense praktyke. Daar is selfs prostitusie binne-in die tempel bedryf. Ten spyte van hervormings deur Asa, Josafat en Joas het die godsdiens van Juda teen die tyd van die agste eeu-profete $( \pm 760-680 \vee C)$ baie heidense elemente bevat. $G$. Fohrer ${ }^{10}$ ) beweer dat dit moeilik was om te sê of dit 'n baälistiese Jahwisme of ' $n$ jahwistiese Baälisme was.

Dié situasie is aansienlik bevorder deur die proses van progressiewe disintegrasie van die ou voorvaderlike voorskrifte. ${ }^{11}$ Die Ou Sinaïtiese verbond met sy streng godsdienstige, morele en sosiale verpligtings was voorheen die basis van die Israelitiese gemeenskap. Sedert die Dawidiese koningskap ingestel is, het daar egter ' $n$ verskuiwing plaasgevind. Hierbo is alreeds gewys op die rol van die Dawidsbeloftes en die Sionsteologie in die vorming van 'n geestelike selfversekerdheid. Dit het egter ook ander gevolge gehad. Omdat die monargie in Juda sy legitimasie nie in die ou Mosaiese verbond gekry het nie, maar in die beloftes aan Dawid, is die ouer verbond geleidelik in die skadu gestel. Dit is aanvaar en ook kulties bevestig dat die Here Sion as sy woonplek gekies het en vir Dawid ' $n$ dinastie vir altyd beloof het. Dit is geglo dat die Here sy gesalfde, die Dawidiese koning, sou beskerm en sy heerskappy sou bestendig.

Hieruit het die opvatting gegroei dat die Here die nasionale Bewaker van Juda is. Die volk moes net die formele kultiese bepalings onderhou, dan sou die Here hulle seën en beskerm. So het die amptelike kultus die dienaar van die volk se teologiese beskouings geword. Dis nie dat die DawidSionsteologie sonder morele eise was nie (vgl. Ps 72:1-4, 12-14). Dis net dat die klem op die beloftes eerder as op die eise geval het. ${ }^{12)}$ Die volk het die onvoorwaardelike beloftes aan Dawid voorkeur gegee bo die voorwaardelike Sinaitiese verbond. Sion het Sinai verdring. Dat hierdie twee verbonde egter nie wesenlik teenoormekaar staan nie, blyk uit die prediking van Jesaja. Hy het die voorwaardelikheid van die ou Sinaïtiese verbond ingebou in sy siening van die Dawid-Sionsteologie. Hy het verder getoon dat die Dawid-Sionsteologie met sy klem op die Here se beloftes en teenwoordigheid altyd gesien moet word teen die agtergrond van die Here se heilsdade en sy morele eise wat daaruit voortvloei. ${ }^{13}$ )

Solank die kultus hierdie onvoorwaardelike teologie gesteun het, was interne verheidening onvermydelik. Daardeur het die staatskultus soos die heidense godsdienste in die algemeen, blote stut en voorspraak van die bestaande orde geword. As napraters van 'n teologie wat die eise van die ver- 
bond verwaarloos het, kon die godsdienstige instellings weinig doen aan die geestelike insinking wat só 'n eensydige teologie noodwendig tot gevolg het.

\section{Geestelike oplewing by die volk}

Geestelike oplewing is by uitstek die werk van God. Die middels wat $\mathrm{Hy}$ gebruik om dit te bewerk, is onder meer die woord, die daad en die Gees.

\subsection{Die woord}

Wanneer koning en volk afdwaal, gebruik God die woord om hulle aan te spreek. Hierdie woord het verskillende kenmerke: ${ }^{14}$

1. Dit is duidelike, verstaanbare taal sonder omhaal van woorde. Op die man af word die sonde genoem, die gevolge aangedui en 'n oproep om bekering gedoen.

2. Dit hang nie in die lug nie, maar het betrekking op spesifieke historiese gebeurtenisse in die lewe van die volk. Daar is geen filosofering of teologisering nie, maar konkrete sake in 'n bepaalde tydsituasie word uitgelig.

3. Dit het meer as een gestalte. Dis vermaning en heilswoord, voorskrif en voorbidding, veroordeling en liefdesverklaring. Want, om die mens in sy gevallenheid te bereik, moet hy op alle moontlike maniere aangespreek word.

4. Alhoewel dit met konkrete, daaglikse sake te doen het, beweeg dit op die geestelike vlak. Dit gaan dus nie om politieke dwang of om liggaamlike geweld nie. Die gevegsterrein is dié van die gees, (die "hart") want dit gaan in die worsteling om die gees van die mens. Is sy gees aan God onderworpe, dán eers kom hy tot nuwe lewe waardeur sy hele lewe verander.

5. Die woord self word gegiet in gewone mensewoorde en menseoptrede. Omdat dit nie met kragwerkings en wondergebeurtenisse gepaard gegaan het nie, was dit op die oog af leë klanke. Die koning kon dit stukkie-vir-stukkie in die vuur gooi sonder dat iets gebeur $(\mathrm{Jr}$ 36). Tog blyk dit eers later dat die woord onvernietigbaar is omdat dit gelaai is met die dinamiek van Hom van wie die woord uitgaan. Heel dikwels het die boodskapper self nooit die effek van die woord gesien nie. Maar hy het geglo in die krag van die Spreker van die woord wat afbreek en platslaan en vernietig maar wat ook bou en vestig $(\mathrm{Jr} 1: 10)$ en tot nuwe lewe wek.

6. In die uitdra van die woord gebruik God swakke mense as sy boodskap- 
pers. Die draers van die woord was mense sonder enige kragoptrede en selfs sonder enige beskerming. Hulle was magtelose boodskappers wat as gevolg van die woord wat hulle gebring het vir hulle lewe moes vlug (Elia, I Kon 19:2), in die tronk gegooi is (Miga, seun van Jimla, I Kon 22:27), weggejaag is (Am 7:12-13), in ' $n$ put gegooi is ( Jr 38:6) en doodgemaak is (Urija, Jr 26:23). Hulle kon nie uit 'n posisie van krag optree nie en was sonder beskerming, uitgelewer aan diégene ter wille van wie hulle moes gaan.

Heldefigure was hulle egter allermins: Jesaja het teruggedeins vir sy taak (Jes 6:5) en Jeremia was teësinnig om sy opdrag uit te voer (Jr 20:7, 14). Hulle was nie invloedryke persone nie en het oor geen besondere gawes beskik nie. Nogtans was hulle die mense wat die lewewekkende woord moes bring. God het hulle gekies, want deur die swakheid van die boodskapdraer het die lewendmakende krag van die boodskapgewer soveel duideliker gespreek.

Maar dit het tog iets besonders van die boodskapdraer vereis: $\mathrm{Hy}$ moes oor ' $n$ geestelike krag en ' $n$ innerlike oortuiging beskik wat slegs gebore word uit 'n persoonlike ontmoeting met die Here, die gewer van die boodskap. Dán eers word hy die draer van 'n dinamiese woord wat uit verval ophef en die wat dood is tot herlewing bring.

\subsection{Die daad}

Wanneer die woord geen reaksie kry nie, gaan dit oor in 'n daad. Die daad van God waarmee $\mathrm{Hy}$ tot herlewing bring, is een waardeur die mens in sy onmag ontbloot word. Dit gebeur wanneer die mens voor die vrees vir chaos of die angs vir die uitsigloosheid te staan kom. $\mathrm{H}$. Faber sê waar die vrees vir chaos oorheers, dáár word godsdienstige ervaring moontlik. ${ }^{15)}$ James E. Loder ${ }^{16)} \mid \hat{e}$ weer klem op die uitsigloosheid. Dis wanneer die mens in grenssituasies gekonfronteer word met die uitsigloosheid dat hy in ' $n$ ontmoeting met die heilige teenwoordigheid van God kom. Wanneer hy God dan te midde van uitsigloosheid ontmoet, kry die lewe weer sin en kan hy die uitsigloosheid oorwin omdat hy die sentrum van sy bestaan buite homself gevind het.

Dit was die situasie tydens die slawerny in Egipte, met die verdrukking deur vyande van buite, met die verwoesting van Samaria en die val van Jerusalem. Dit was nie gebeurtenisse wat maar per toeval plaasgevind het nie. Nog minder was dit blote wraaksug van die kant van God. Dit was krisisgeleenthede waar die chaos en die uitsigloosheid voor die volk kom opdoen het en hulle gedwing het tot ' $n$ ontmoeting met die heilige God.

Meestal word die val van Samaria en Jerusalem as die grootste rampe in die geskiedenis van die volk beskou. Menslik gesproke, was dit ook so. Maar gesien vanuit die hoek van God se koninkryk was dit die beste dinge wat kon gebeur het.

Die val van Jerusalem is welbekend as ' $n$ gebeurtenis wat ' $n$ totaal nuwe dimensie verleen het aan die godsdiens van Juda. Die krisis en uit- 
sigloosheid van dié ramp het die volk genoop om sy godsdiens te re-evalueer. In die krisis het Juda in ' $n$ ontmoeting met die heilige teenwoordigheid van die Here gekom. Daarna was niks meer dieselfde nie. Geen ander gebeurtenis naas die verlossing by die Rietsee het soveel effek gehad op die godsdiens van Juda en sy begrip van die Here as juis die val van Jerusalem nie.

Die effek van die val van Samaria is egter minder bekend en moet dus van nader bekyk word. Daar is vroeër gewys op die eensydige beskouing van die Sionsteologie en op die geleidelike sinkretisme wat in Juda ingesluip het sonder dat daar in die Suidryk wel veel teenstand daarteen opgebou is. Daar is ook gewys op die andersoortige situasie in die Noordryk waar die openlike konfrontasie met die Baälgodsdienste vroeg reeds sterk weerstandsgroepe laat ontstaan het.

Die val van Samaria het 'n groot verandering aan hierdie situasie te weeg gebring. Met die aanval van die Assiriërs op Samaria het groot getalle Israeliete in die Noordryk suidwaarts na Juda toe gevlug. Argeologiese ondersoeke lewer bewys dat die bevolkings van Jerusalem en ander Judese stede in die laaste kwart van die agste eeu voor Christus verdubbel of selfs verdriedubbel het. ${ }^{17)}$ Die tien stamme is dus nie "verlore" nie, maar het in groot getalle na Juda toe gevlug en is mettertyd opgeneem in die Suidryk.

' $n$ Groot aantal van hierdie vlugtelinge was uit die toegewyde groepe en hulle het hulle heilige geskrifte met hulle saamgebring. Dit het ingesluit geskrifte wat ons nou ken as Hosea en Deuteronomium. Met hierdie nuwe inspuiting van Mosaïse Verbondsteologie kon Jerusalem nie voortgaan om net 'n koninklike heiligdom te wees nie, maar word dit nou die sentrum van die Mosaïese geloof soos so duidelik in Deuteronomium uiteengesit. ${ }^{18}$ )

Alhoewel dit aanvaar kan word dat hierdie invloed alreeds in die tyd van Hiskia 'n herlewingsinvloed uitgeoefen het, was dit eers 'n eeu later, in die tyd van koning Josia, dat die invloed werklik deurgewerk het. Met die val van Samaria is die kern van die hervormingsparty in Juda geskep en is die grondslag gelê vir 'n dinamiese konfrontasie met die kruipende heidense opvattings en die verontagsaming van die bepalings van die ou Sinaïtiese verbond. ${ }^{19}$ ) Sodoende het die val van Samaria die middel geword waardeur insinking in Juda gestuit is en die godsdiens van Juda gesuiwer en verryk is.

Dis bekend dat die hervormings van Josia wat op grond van die invloed van hierdie vlugtelinge uit Samaria plaasgevind het, kortstondig van aard was. Nogtans het die nuwe gees wat hulle gebring het en die geskrifte wat hulle bewaar het in die profete hulle voortgang gevind en nuwe lewe gebring wat vir altyd sou bly spreek.

Op dié wyse neem God krisisse, chaos en uitsigloosheid in sy diens om geestelike insinking te stuit en herlewing te bewerk.

\subsection{Die Gees}

Die middel wat God by uitstek gebruik om geestelike herlewing te bewerk, is sy Gees (rûạ̣). ${ }^{20}$ ) In die vroeër tydperk het die Gees die rigters bekragtig om 
Israel van onderdrukkers te bevry sodat hulle in vrede 'n nuwe lewe as God se volk kan begin. Die Gees het ekstatiese profete soos Samuel en Elia instaat gestel om dade te verrig wat die volk uit sy doodslaap moes wakkerskud. Maar dis veral die woord wat die klassieke profete verkondig het wat gelaai was met die dinamiese krag van die Gees. Daarmee het God op die afval gewys, tot nuwe lewe geroep en mense se lewens verander. In die na-ballingskaptyd kondig die profete egter 'n nuwe tydperk aan. Dis 'n tydperk waarin die Gees van die Here op 'n totaal ander wyse sou werk as voorheen: wyer, dieper, bestendiger, ingrypender en met die oog op nuwe innerlike lewe.

Dan is die werking van die Gees nie beperk tot sekere enkelinge en ampte nie, maar kan $\mathrm{Hy}$ enigeen bekragtig om 'n nuwe lewe te voer en om met vurige entoesiasme die wil van die Here met profetiese ywer te verkondig ( $\mathrm{Jl}$ $2: 28-29$ ). Die werking van die Gees verkry dan ook 'n permanensie omdat die werking daarvan van binne geskied. Dit gebeur wanneer die mens die nuwe "hart", waarna ons reeds gewys het, ontvang. Hierdie gawe kom van die Gees van God. Hy skenk die nuwe "hart", gee 'n nuwe wilsbeslissing en nuwe besluitnemingskategorieë (Esg 11:19-20; 18:31; 36:26-27). Deur die "hart" van die mens te verander, skep die Gees dus ' $n$ nuwe mens. Só ' $n$ mens ontvang die wil en begeerte om God se wil te doen en so in 'n nuwe verhouding met Hom te kom.

Maar die Ou Testament beklemtoon ook die lewenskragtigheid van die Gees van God. Dit herskep nie net die enkeling nie, maar is ook instaat om 'n hele volk wat soos dorre doodsbeendere is, weer tot nuwe lewe en nuwe hoop te bring (Esg 37:1-14). Net soos die reën wasdom bring op die dorre aarde, so bring die Gees 'n skynbaar gestorwe volk tot lewe en groei (Jes 44:3).

Uiteindelik is dit dus die Gees van God wat enkeling en volk tot geestelike herlewing wek, wat insinking tot oplewing bring, wat 'n nuwe verhouding tussen God en mens en tussen mens en medemens bewerk.

\section{NOTAS}

1. G. von Rad, Genesis, London 1963, 102. Vgl, ook C. Westermann, Genesis, 1. Teilband, Kapitel 1-11, Neukirchen 1976, 408-9.

2. W. McKane, Proverbs, London 1970, 310.

3. John Bright, A history of /srael, London 1981, 260-2

4. Klaus Koch, The prophets, Volume One, London 1982, 52-3.

5. Niels-Erik Andreasen, "Town and country in the Old Testament", Encounter vol. 42/3, (1981), 259-75, word hier gevolg.

6. M. Greenberg, "Religion, stability and ferment" in A. Malamat (red.), The age of the monarchies: Culture and society, Volume Four-Il. Jerusalem 1979, 108.

7. G. Fohrer, History of /sraelite religion, New York 1972, 136. Vgl. egter ook die effek van die Kanaänitiese godsdienste op bepaalde Ou-Testamentiese opvattings soos aangetoon deur K. Jaros, Geschichte und Vermächtnis des Königsreiches /srael von 926 bis 722 v. Chr, Bern 1979, 65-94.

8. G. Fohrer, a.w., 126-7.

9. F.M. Cross, Canaanite Myth and Hebrew Epic, Cambridge, Mass. 1980, 238-41.

10. G. Fohrer, a.w., 132. 
11. John Bright, a.w., 289 word hier gevolg.

12. Idem., 294.

13. Idem., 295.

14. W. Zimmerli, Grundriss der alttestamentlichen Theologie, Stuttgart 1972, 88-9; .C. Westermann, Theologie des Alten Testament in Grundzügen, Göttingen 1978, 12-18; W. Eichrodt, Theology of the Old Testament, Vol. One, London 1961, 342-4.

15. H. Faber, "Zicht op de structuur van de godsdienstige ervaring: twee boeken", NTT, vol. 3611982), 311-31, veral 315, 317, 322-3.

16. James E. Loder, The transforming moment, San Francisco 1981.

17. Magen Broshi, "Estimating the population of ancient Jerusalem" BAR vol. 4/2, (1978) 10-5, veral 11-2; M. Broshi, "The growth of Jerusalem in the reigns of Hesekia and Manasseh" Isr Exp/ Jn/, vol 24(1974), 21-6.

18. M.M. Eisman "A tale of three cities", BA vol. 41/2(1978), 47-60. veral 52.

19. John Bright, a.w., 297.

20. Vgl. W. Vosloo, "Rūaḥ/gees in die Ou Testament", Skrif en Kerk 4/2(1983), 40-68, veral $57-62$. 